\title{
Frederick Antal and the Marxist challenge to art history
}

\author{
Jim Berryman \\ The University of Melbourne, Australia
}

\begin{abstract}
First published in 1948, Frederick Antal's Florentine Painting and its Social Background was an important milestone in Anglophone art history. Based on European examples, including Max Dvořák, it sought to understand art history's relationship to social and intellectual history. When Antal, a Hungarian émigré, arrived in Britain in 1933, he encountered an inward-looking discipline preoccupied with formalism and connoisseurship; or as he phrased it, art historians of 'the older persuasion' ignorant of 'the fruitful achievements of modern historical research.' Despite its considerable scholarship and erudition, Antal's book was not warmly received, largely because he had used historical materialism to understand the production of art and the development of styles. Antal's class-based account of the social position of the artist and the role of the patron in determining the emergence of early Renaissance styles was especially controversial. However, although Marxist analysis was used to challenge the assumptions of Anglo art history, it was not Antal's intention to weaken art history's disciplinary autonomy. With historical materialism, he sought to place art history on a firmer historical footing. Most importantly, this approach was compatible with the discipline's Central European tradition, where art-historical scholarship was framed by questions of method and based on broad historical research. Without defending its more deterministic features, this article supports a re-evaluation of Antal's book, as an important forerunner of interdisciplinary art scholarship.
\end{abstract}


It considers why Antal's legacy has not endured, despite the 'social history of art' enjoying widespread acceptance in English-speaking art history in later decades.

\section{Keywords}

Frederick Antal (1887-1954), art historiography, historical materialism, Renaissance art, social history of art

\section{Corresponding author:}

Jim Berryman, The University of Melbourne, University Library, Victoria 3010, Australia. Email: jimb@unimelb.edu.au

\section{Introduction}

Frederick Antal's major work, Florentine Painting and its Social Background: The Bourgeois Republic Before Cosimo de' Medici's Advent to Power, was first published in Britain by Kegan Paul in 1948. Written between 1932 and 1938, the book's publication was delayed by the events of the Second World War. Although largely forgotten today, Antal's book is significant: it is among the earliest scholarly studies to present a Marxist interpretation of the origins and development of Renaissance art. Perhaps most importantly for modern readers, it pioneered an interdisciplinary approach to art-historical research. Drawing on specialist literature in economic and social history, it set out to dispel the myth of 'Florence as a community living in conditions of carefree prosperity, general harmony and timeless beauty' (Antal, 1948: 5). At the time of its publication, Antal's book presented a challenge to Anglophone art history, then largely preoccupied with questions of aestheticism, formalism and connoisseurship. Antal's call for 'co-operation between the various branches of historical science' (ibid.: 8) was greeted with suspicion by a discipline protective of art as a culturally autonomous field. 
Antal, a Hungarian art historian and graduate of the esteemed Vienna School of Art History, had intended to produce an ambitious three-volume history of Florentine painting, ranging from the $14^{\text {th }}$ to the $16^{\text {th }}$ centuries. This project was never realised; his death, in 1954 , meant that only one volume was published. Commencing with Giotto and concluding with Masaccio, Florentine Painting and its Social Background examined the art of the Trecento and early Quattrocento. Despite commending Antal for his erudition and scholarship, most contemporary critics condemned his book for its Marxist orientation. Millard Meiss, a scholar of Trecento art, reviewed it for The Art Bulletin. Meiss declared the book's problems 'arose from Antal's rigid social determinism and other assumptions of his orthodox Marxist point of view' (Meiss, 1949: 144). Another review, published in The Journal of the History of Ideas, noted, 'Antal, following Karl Marx, believes that works of art, like any other aspects of a culture existing within a class society, ought to be explained as the outgrowth of the conditions of production and property' (Mommsen, 1950: 370). A similar sentiment was expressed in The Burlington Magazine: 'Unfortunately Dr Antal directs his researches into the narrow channels of class-conscious dialectics, which confuse and disappoint to an extent that it makes objective criticism a difficult and irritating task' (Gronau, 1948: 298).

It is fair to say that Antal's book has never recovered from its contemporary critical reception. Its reputation as an exemplar of reductive Marxist historiography, crudely applied to the liberal arts, has gone unchecked in the decades since it was published. Antal's writings have not been included in anthologies of key art history texts and are now largely unknown to students of the discipline. In the words of Deborah Krohn, 'Antal's book is a relic and is not read seriously by students of early modern art or culture' (Krohn, 1999: 95). In the decades since its publication, Florentine Painting and its Social Background has been republished only once, in 1986, by Harvard University Press. It is remembered, if at all, as a methodological dead-end, an artefact of pseudoscientific dialectical materialism. This assessment has 
overshadowed Antal's principal aim: to open art history to 'specialised branches of learning' and 'to make use of this knowledge in the service of art history' (Antal, 1948: 5). Although unfamiliar to English-speaking art historians, Antal's approach was consistent with modern scholarship from Central European art history, especially Max Dvořák, his teacher in Vienna.

Although no reference to Marxist critical theory can be found in Florentine Painting and its Social Background, the book was evidently based on historical materialist interpretations of class struggle. Like Arnold Hauser, whose Social History of Art was published in 1951, Antal may have sought to avoid controversy by describing his methods as 'sociological' rather than Marxist. But this hardly assuaged the concerns of his critics. Cold War anxiety, then widespread in the social and political arena, extended to the cloistered world of Anglo-American art history (Orwicz, 1985). In humanist academic circles, Cold War tension was manifested in distrust of, and sometimes hostility towards, methods and practices derived from the social sciences. Michael Orwicz has argued that a liberal/conservative tradition of art history, based on an autonomous conception of culture, obstructed the use of social scientific approaches within the discipline. In the 1950s, writes Orwicz, 'the principle underlying the humanities placed "man"/“individual"/“culture" outside of social and material realities' (ibid.: 53). The ideological division of 'culture/society and individual/social group,' says Orwicz, 'organized much of the practice of art history in the academic system' (ibid.). This attitude was deep-rooted and persisted in art history for some decades, long after social theory had established its credentials among other branches of the liberal humanities.

Jeremy Tanner's anthology, The Sociology of Art, outlines the origins and development of aesthetic and social thought. Since they were 'institutionalised' together as academic disciplines in the $19^{\text {th }}$ century, the relationship between art history and sociology has been problematic, marked by periods of convergence and divergence: 
As they acquired an independent social basis for their work, art historians redefined their discipline in such a way as to marginalise sociological concerns, and sociologists developed specific attitudes towards art and methods of analysis which were increasingly peripheral to art historians' core interests. (Tanner, 2003: 2)

These differences were exacerbated by the expansion of the modern academy, which encouraged the differentiation of disciplines and the development of distinctive programmes of study. The perception of sociology as an instrumental social science reflected the success of Max Weber's studies of bureaucracy and economic organisation, which according to Tanner were more influential in Anglo-American sociology than Weber's studies of religion (ibid.: 14). Both disciplines were concerned with the problem of individual autonomy and the distinctiveness of aesthetic value in modernity. However, whereas art historians were focused on the characteristics of 'authentic' art objects and artistic individuality, sociologists, insofar as they were interested in art, examined the effects of social processes (rationalisation and secularisation) on the formation of aesthetic culture in modern society (Bourdieu, 1993; Habermas, 1989).

In the post-war decades, few art historians were more influential than Ernst Gombrich, director of the London Warburg Institute. Gombrich could not countenance art historical research in which sociology played a prominent role. In 1979, he continued to oppose the tendency, as he saw it, to view art history as a 'handmaiden of sociology' (Gombrich, 1979: 132). Gombrich was not opposed to ideas that crossed disciplinary boundaries; Karl Popper's epistemological philosophy, critical rationalism, was a major influence on Gombrich's key study of pictorial representation, Art and Illusion, first published in 1959. But Gombrich did share Popper's deep distrust of sociology. Indeed, he would consciously apply Popper's liberal 
political philosophy to art history as an alternative to 'sociologism' (Azatyan, 2010; Berryman, 2017). Based on these attitudes, it is not hard to see how the social history of art was excluded from key intellectual debates in post-war British art history. In the late-1970s, however, a renewed interest in the relationship between art history and sociology was evident (Wolff, 1983). This dialogue was encouraged by the 'New Art History', an interdisciplinary approach that combined elements of feminism, structuralism and critical theory (Harris, 2001).

With entire chapters dedicated to the economic and religious history of late-medieval Italy, Florentine Painting and its Social Background is an attempt to understand art history's relationship to social and political history. Although, as Krohn contends, lingering fears of communism may have affected the book and its reception, the Cold War atmosphere cannot explain why Antal's methods failed to gain traction. As noted by Millard Meiss in his review, other disciplines had successfully adapted historical materialist principles to their research:

Antal's book is one of the first attempts to trace the origins of an extended period of art in contemporary social structure. Though similar methods of interpretation have become familiar in other branches of culture since the rise of Marxist criticism, they have not often appeared in the history of art. For our field this book is therefore an event. (Meiss, 1949: 144)

Antal voiced frustration about art historians of 'the older persuasion' who, owing to their narrow focus on style, were ignorant of 'the fruitful achievements of modern historical research' (Antal, 1966: 186). 'Living in their ivory tower,' as he put it, 'they think that to adduce the results of social or ecclesiastical history must degrade an art-history which should, at least theoretically, be reserved to masterpieces' (ibid.). Antal was encouraged by recent scholarship in archaeology, art history's kindred discipline, especially the work of V. Gordon 
Childe. In Man Makes Himself, first published in 1936, Childe synthesised his knowledge of European prehistory with insights from historical materialism. His 'social archaeology' was based on a Marxist view of history in which societal progress was driven by technological and economic revolutions (Childe, 1936). Art and culture were shaped by material and social forces. Childe's archaeological writings pointed the way for art history, which Antal was keen to explore. In Antal's words, they 'established the closest possible relations between social structure, religion, mental outlook, and art' (Antal, 1966: 186).

For Antal, Marxism was not just an ideology or a perspective through which art history could be reinterpreted and reanalysed, on class-based terms. Historical materialism was a 'scientific' method, which could add rigour and stability to art-historical research. In 1946, in a letter to Georg Lukács, Antal wrote: 'If my books have significance, it lies in my having used a much wider range of specialised literature in every branch than has been customary so far, in order to construe the developments in art on a Marxist basis' (Antal, 1979[1946]: 123). Antal, however, was not a Marxist theoretician. He was, in his own words, an art historian who wrote art history on a Marxist basis. Historical materialism was a strategy he deployed to understand the production of art and the development of styles. This system was more comprehensive than art-for-art's-sake formalism or unhistorical connoisseurship, the approaches of Anglo art history that he derided. Most importantly for Antal, historical materialism was compatible with the discipline's Central European tradition, where art-historical scholarship was framed by questions of method and based on broad historical research.

While Antal used Marxist analysis to challenge the assumptions of Anglo art history, it was not his intention to weaken art history's disciplinary autonomy. Rather, with historical materialism, he sought to place art history on a firmer historical footing. Florentine Painting and its Social Background was therefore meant to demonstrate how a Marxist concept of social history could be applied to art history, as it had been applied to other human sciences. Without 
defending its more deterministic features, this paper supports a re-evaluation of Antal's book, as an important forerunner of interdisciplinary art scholarship. It considers why Antal's legacy has not endured, despite the 'social history of art' enjoying widespread acceptance in Englishspeaking art history in later decades.

\section{Antal and art history}

In his essay entitled 'Remarks on the Method of Art-history,' Antal broached the question: 'Why is it that a tendency still remains among some art-historians to put a break upon efforts to broaden art-history by a study of social history?' (Antal, 1966: 184). This essay was originally published in the Burlington Magazine in 1949, the year after Florentine Painting and its Social Background, and was intended to provide a rationale for his social history approach. The question was therefore aimed at English art historians, for whom social history was foreign. Antal was conscious of the differences between English art history and the discipline's Central European academic tradition. English art history, as he saw it, had evolved from a $19^{\text {th }}$ century tradition of art criticism and connoisseurship. This 'impressionistic' art criticism 'was largely concerned to describe the fleeting reactions of a sensitive beholder before a work of art' (ibid.: 185). Despite efforts in the early-20 $20^{\text {th }}$ century to 'modify this extreme subjectivism by a more controlled, more constructed attitude,' English art history was still characterised by its 'unhistorical approach' (ibid.). This was in contrast to European art history and its historical outlook:

The severely historical spirit of the school of Vienna and the resolutely antiart-for-art's-sake attitude of Warburg together paved the way for a deeper, richer and less nebulous study of art-history, which can draw upon the very tangible results of the historical disciplines, in particular of social and 
economic, of political and religious history (not exclusively of the history of literature and philosophy) as well as of an historically-intentioned social psychology. (ibid.: 179)

To understand Antal's critique of the methodological limitations of 'unhistorical' art history, it is necessary to first understand his arguments in favour of an alternative approach, one based on an understanding of social history. But to begin with, some biographical context is required. Frederick (Frigyes) Antal was a Hungarian art historian born in Budapest in 1887. His involvement in the short-lived Hungarian Republic of Councils in 1919, the so-called Hungarian Soviet Republic, occasioned his exile from Hungary after 1920, following the defeat of the revolution. Antal lived in Berlin from 1922 until settling permanently in Britain in 1933, where he died in 1954, before completing his multi-volume history of Renaissance art (Blunt, 2004[1971]). With Fritz Saxl, Johannes Wilde, Ernst Gombrich and Rudolf Wittkower, Antal was among several notable Austro-Hungarian and German art historians who settled in London following the rise of the Third Reich. These scholars, predominantly Jewish or of Jewish origin, had an enormous impact on the development of the discipline in Britain. After the war, the teaching of art history became closely aligned with German-speaking academic methods. For as Daniel Snowman has noted, it was one of many fields that European émigrés would help to professionalise (Snowman, 2002: 340).

After fleeing Germany in 1933, Antal may have considered Britain to be a temporary refuge. Antal, it seems, had planned to find work in the United States, along with many other Jewish intellectuals escaping Nazism (Frank, 2009: 316-17). In 1934, the Academic Assistance Council (AAC) in London referred Antal to the Emergency Committee in Aid of Displaced Foreign Scholars; the Emergency Committee was established in New York in 1933 by American academics, for the purpose of employing refugee German scholars in American 
institutions. Antal's referees included Kenneth Clark and Herbert Read; a recommendation by Read stated, 'I do not know of any art historian whose work can, in my opinion, be compared in importance to Dr. Antal's' (ibid.: 317). However, a testimonial by historian Walter Adams, then secretary of the AAC, cautioned: 'His vigorous personality may make him [Antal] a difficult colleague for some people' (ibid.). Probably because of his Hungarian citizenship, Antal's application for an American position was ultimately unsuccessful; he remained in London for the rest of his life.

Antal never held a regular academic post in London but he did occasionally lecture at the Courtauld Institute where, according to Anthony Blunt, 'he exerted considerable influence on a small group of students, to whom his enthusiasm and his astonishing range of knowledge were an inspiration' (Blunt, 2004[1971]). John Pope-Hennessy, then a young art historian, remembers Blunt being especially 'captivated' by Antal's Marxist convictions (PopeHennessy, 1991: 305). Pope-Hennessy became acquainted with Antal in the 1930s when Antal was working on Florentine Painting. Despite rejecting his 'generalised style history and rudimentary sociology,' Antal left a lasting impression:

Antal was a very different figure; he was an orthodox Marxist, and his concern, throughout a long career, was to establish an equation between society and style. Central European in appearance and cast of mind, he had a low, rather mellifluous speaking voice which was in striking contrast to his radical beliefs. (Pope-Hennessy, 1991: 304)

With his compatriot Arnold Hauser, Antal is best remembered by art history as a pioneer of the social history of art, a Marxist project that sought to interpret the history of art according to historical materialist principles (Stirton, 2006). However, despite their ideological 
affinities, there were significant differences between Hauser and Antal. Unlike Hauser, a generalist cultural historian, whose sweeping sociological research encompassed the entire history of Western art and literature, from the 'Stone Age to the Film Age,' Antal was a specialist art historian. His other major monographs, posthumously published, focused on English art of the $18^{\text {th }}$ century (Antal, 1956, 1962). Also, as noted, Antal was keenly interested in the methods of academic art history. His essay, 'Remarks on the Method of Art-history,' republished in a collection of essays in 1966, was described by Anthony Blunt as a 'statement of his [Antal's] own credo' (Blunt, 2004[1971]).

Antal's interest in the methods of art history can be traced to his education, especially the influence of his two principal teachers, both of whom were major theoreticians of the discipline. The first was Heinrich Wölfflin, whose formalistic method Antal encountered while studying art history in Berlin. The second was Max Dvořák, who supervised Antal's doctoral dissertation in Vienna. Dvořák, a Czech-born art historian and curator, was a central figure in the Vienna School of Art History (Rampley, 2003, 2013). His key concept, Geistesgeschichte (the history of ideas), had a profound impact on Antal's intellectual development. The Vienna Art Historical Institute, located within the Austrian Institute of Historical Research, was more compatible with Antal's concept of art history as an historical science (Stirton, 2013). In 'Remarks on the Method of Art-history,' Antal stressed his indebtedness to the Vienna ethos: 'The Viennese school of art-history, to which Riegl, Wickhoff, and Dvořák belonged, gave a far more prominent place to history and the historical development of style' (Antal, 1966: 176). This was in contrast with Wölfflin's synchronic model of formal analysis, which was autonomous and largely unhistorical. Wölfflin's new visual science, says Antal, 'conceded, relatively, the smallest place to history' and 'reduced the wealth of historical evolution to a few fundamental categories, a few typified schemas' (ibid.: 175-6). Antal would reject Wölfflin, 
'who considered art to be detached from the ideas of their time, and who stressed in art the “eternal”, the "absolute”, [and] purely formal values' (ibid.: 176).

Thus, whereas Wölfflin sought to isolate styles from their historical contexts, by creating an autonomous method of stylistic analysis based on the formal characteristics of artworks, Dvořák dealt with art history as part of intellectual history. In Dvořák’s words, 'a great artist never stands absolutely outside the spiritual and intellectual ferment of his time and if the threads binding him to it are invisible to us then it means that we have failed to look deeply enough either into his art or into the age in which he lived' (Dvořák, 1984: 71). Dvořák’s comprehensive understanding of art and its connection to broader history strongly appealed to Antal. The pioneering example of this approach was found in Dvořák's history of the art of the Van Eycks, published in 1904. According to Antal, Dvořák could not explain how oil painting had suddenly emerged in $15^{\text {th }}$ century Flanders without recourse to social and economic history. For answers to 'the enigma of the Van Eyck brothers,' Dvořák looked beyond conventional art-historical sources, 'in books of economic history' that explored 'the new bourgeois culture in Flanders, of which this art was a product' (Antal, 1966: 177). In this important study, Dvořák had not only established a connection between art and its wider social and economic milieu; he had also demonstrated how the art historian's knowledge of art could be enhanced by learning from other disciplines. Although Antal ultimately rejected Geistesgeschichte in favour of Marxism, Dvořák's influence remined conspicuous in Florentine Painting and its Social Background. Antal wrote in the introduction:

As Dvořák has pointed out, economic facts throw light upon the whole development of art, even if only indirectly. In speaking of the art of the van Eycks, he remarked that art history had so far offered no explanation of its sudden emergence; the sources of the new bourgeoise culture, of which this art 
was a product, were not known, since the growing importance of Flanders is 'mentioned only in books of economic history which no one ever reads'. As matters stand to-day, greater knowledge and understanding of the origins of the Renaissance are often to be found in general handbooks of economic history than in works on art history. (Antal, 1948: 4)

\section{Towards a social history of art: Antal's 'methodological turn'}

Antal's interest in the nexus between art and society began in the years before the First World War. And yet, the importance of sociology would remain underdeveloped in Antal's work until the early 1930s. Antal's intellectual journey was not a straightforward trajectory. For most of the 1920s, when he began to build a reputation as a scholar, his method of inquiry continued to follow Dvořák's Geistesgeschichte. During this period, Antal became known for a handful of specialist articles that dealt with stylistic aspects of late Gothic and Quattrocento painting (Antal, 1924/1925; Antal, 1925). This output was largely conventional in scholarship and did not correlate with his political outlook; as noted, Antal had been actively involved in the Hungarian proletarian dictatorship in 1919. His article 'Thoughts on the Development of Trecento and Quattrocento Painting in Sienna and Florence', published in the 1924-25 volume of Jahrbuch Für Kunstwissenschaft, prefigured Florentine Painting and its Social Background, but without expressing the ideological viewpoint of the later work. Antal did not attempt to reconcile his scholarly and political viewpoints until the early 1930s, when he became interested in the possibility of a Marxist interpretation of art history.

Antal's connection to political Marxism predates his Marxist art history by almost two decades. During the First World War, he was a member of the Sunday Circle, an informal group of Budapest intellectuals comprising Georg Lukács and Béla Balázs. This association would lead to his involvement in the short-lived communist regime in Hungary. Under Lukács, 
the People's Commissar for Public Instruction, Antal was appointed to lead the Directorate of Arts and Museums. One of his first tasks in this role was to oversee the nationalisation of private art collections and the preparation of an exhibition from this material (Wessely, 1979: 116). Antal's foray into revolutionary politics, however, did not last long. It ended when the so-called Hungarian Soviet Republic was defeated by counter-revolutionary forces. Antal focused his attention on scholarly pursuits; after moving to Berlin in 1922, he edited the academic journal Kritische Berichte, an art review dedicated to problems of art-historical methodology. It was during this period that Antal's preoccupation with Dvořák's history of ideas was most evident.

As an exponent of Dvořák's Geistesgeschichte, Antal sought to identify the intellectual and spiritual outlook of a period through the study of its art. Following this approach, he closely analysed the stylistic characteristics of artworks and artists to understand the ideology (or Weltanschauung) of their time. In his 1924 article on Florentine and Sienese painting of the Trecento and Quattrocento, Antal devised the category the 'Giottoesque' to describe a classicist tendency discernible in the art of this period. However, as his research grew in scope and ambition, Antal came to realise that a formal description, based on Giotto's style, was too vague and general. Furthermore, an analysis of Renaissance painting devoted to formal features, at the expense of subject matter, failed to adequately explain the social, philosophical and religious dimensions of this art. Antal would henceforth seek to understand a style in its totality. When defining style as an art-historical concept, he would pay equal attention to form and content. The social history of art would therefore stress the interconnectedness of subject matter, form and social referent. Antal presented his new concept of style in 'Reflections on Classicism and Romanticism,' an important essay first published in 1935: 
If we take sufficient account of content we realise at once that styles do not exist in a vacuum, as appears to be assumed in purely formal art-history. Moreover, it is the content of art which clearly shows its connection with the outlook of the different social groups for whom it was created, and this outlook in turn is not something abstract; ultimately it is determined by very concrete social and political factors. If, therefore, we wish to understand a style in its totality, we must trace its connection with the society in which it has its roots. (Antal, 1966: 2)

Following Dvořák, Antal continued to draw on the literature of cognate disciplines to gain a better understanding of art and its relationship to society. Yet, whereas Dvořák had used this material to contextualise the history of ideas, Antal employed social and economic history to determine actual developments in art history. Dating from the early 1930s, Dvořák’s concept of Geistesgeschichte was substituted for a Marxian notion of historical materialism. Henceforth, he would cease to view works of art as the embodiments of intellectual and spiritual currents, as the objectification of abstract thought. Instead, art was a form of material culture that expressed the social and political conditions of its production.

For Antal, historical materialism offered art historians unique sociohistorical possibilities unavailable to other approaches. The first draft of Florentine Painting and its Social Background was completed in 1933. Although Antal is best known for this book, he was not primarily interested in the art of the period that it covers. Rather, Antal's area of specialisation was Mannerism, the art of the Cinquecento. He had been working on a major study of $16^{\text {th }}$ century Florentine painting in the late-1920s but decided not to publish this manuscript. It was at this time that Antal became increasingly interested in the Marxist interpretation of history and its potential application to art history. He felt, therefore, that he 
needed to master the social and economic history of Florence before he could write a full history of Florentine art (Blunt, 2004[1971]). Antal also came to realise that the crucial revolution in the development of Florentine art had occurred in the late- $14^{\text {th }}$ and early- $15^{\text {th }}$ centuries. As John Pope-Hennessy explains:

His initial intention was to stake out the case for Marxist art history in a volume on the Cinquecento. That this was never written was a serious loss, but he found first that it was impossible to write on the sixteenth century if he had not written on the fifteenth, and then that the fifteenth century could be discussed only after study of the fourteenth. (Pope-Hennessy, 1991: 304)

To demonstrate how competing class interests affected pictorial styles, Antal consolidated a vast amount of research about the social and economic history of Florence. Antal's Marxist thesis was based on the belief that the impetus of modern history was to be found in the struggle of the bourgeoisie for economic and political domination. Because the importance of art created (or sponsored) by the bourgeoisie was proportionate to its growing social influence, Marxist interpretations of class had major implications for understanding the history of art. Antal's 'methodological turn' coincided with a six-week tour of the Soviet Union in 1932, the year before he settled permanently in Britain (Wessely, 1979: 118). Antal visited Soviet art museums and, on his return to Germany, recorded his impressions in Kritische Berichte (Antal, 1976[1932]). What distinguished communist art museums from their counterparts in bourgeois countries was the way in which they organised and exhibited their collections. Lee Congdon has summarised Antal's impressions of Soviet museums (Congdon, 2001: 28-9). Soviet art historians did not conceive of style in abstract aesthetic terms, but rather as historical manifestations of concrete economic relations and their resultant class ideologies. 
Most importantly, Soviet curators installed gallery panels and tablets to impart economic and political information to museums visitors about contemporary aesthetic ideologies, so 'museum visitors could see for themselves how the history of art, far from being autonomous, reflected economic developments' (ibid.: 28). While Antal cautioned against the danger of subordinating the artistic quality of exhibitions to ideological interpretations, he believed that Soviet museums were on the right track. Congdon quotes Antal on this point: 'An exhibition based upon historical materialism can at the same time emphasise quality, and hence be artistically effective and educational, and also consistently Marxist; that is, not merely artistic, not simply a matter of taste' (ibid.: 29, original emphasis).

\section{Florentine Painting and its Social Background}

Florentine Painting and its Social Background opens with a comparison of two paintings, one by Masaccio and the other by Gentile da Fabriano. These paintings, which hung side by side in the National Gallery in London before World War Two, were both painted in Florence within a year, in 1426 and 1425, and were both pictures of the Madonna and Child. And yet, as Antal notes, in terms of colour, composition, spatial arrangement and modelling, there is a vast difference between the two paintings. These striking dissimilarities would prompt Antal's question: 'How could two such widely differing pictures have been painted in the same town and at the same time?' (Antal, 1948: 2). This question would not only serve as a starting point for Antal's social history of Florentine painting. More broadly, it would also necessitate a new approach to understanding the problem of style in art history. For, according to Antal, this puzzle could not be adequately explained by the conventional analytical methods available to art historians. Although formalism could describe these stylistic differences, it could not offer a valid explanation for them. A formal analysis would merely: 
Seek to explain the difference between these two pictures by saying that each belongs to a different stylistic trend, one to what it calls the 'classic' or 'renaissance' style and the other to the 'late-Gothic'. Each style has its own specific development, and art history is the history of these styles. But can styles be explained merely by putting labels on them and describing their characteristics? In other words, is the co-existence of various styles in the same period explained by merely stating the fact that they do co-exist? (ibid.)

Before Antal could answer these questions, he had to deal with the art-historical problem of period styles. For Antal, progress in art did not follow a linear trajectory of formal innovation. He cited Riegl and Dvořák, the two great historians of the Viennese school, to argue this point. Both had shown that 'increasing naturalism was not necessarily the hall-mark of a more recent style; on the contrary, chronological development often ran in the opposite direction' (Antal, 1948: 3). Florentine painting was a case in point. According to Antal, after Masaccio no painter of the second half of the $15^{\text {th }}$ century had carried on the naturalistic tradition. Instead of developing along these lines, 'all the painting of this period can be classed, more or less, as "late-Gothic" (ibid.). Thus, progressive styles do not always run parallel to an art-historical timeline, and a more recent style is not always more progressive by virtue of being newer. It becomes clear to readers of Antal's book that artistic progress is not based on a connection between art and chronology, but rather an association between art and progressive ideology. Whereas Masaccio's naturalism reflected the rational, classicist and secular outlook of the progressive middleclass, Gentile da Fabriano's 'late-Gothic' style reflected the irrational and religious outlook of reactionary middleclass elements. The coexistence of these different styles, in the same town and at the same time, could therefore be explained by the coexistence 
of different class strata and their different ideological viewpoints. This, in essence, was Antal's thesis, as propounded at length in Florentine Painting and its Social Background.

The Florentine bourgeoisie of the Trecento and early Quattrocento was not a homogenous class structure. Antal's account of Florentine society is not based on class conflict between the middleclass and the aristocracy, or between the upper and lower-middleclass strata. Rather, to make sense of this period and its art, he focused on the upper-middleclass. This powerful mercantile class was composed of two elements: a cultured, progressive and intellectual element and a rival conservative element. Differences in their respective cultural preferences, according to Antal, determined differences in artistic styles. Whereas both elements of the upper-middleclass possessed economic capital, cultural capital was concentrated in the progressive upper-middleclass. This social stratum used naturalism and classicism to distinguish their aesthetic preferences from the popular and aristocratic tastes of the other classes. The styles of Giotto and Masaccio best exemplified the intellectualism and rationalism of the progressive middleclass. These advanced painters were contrasted with Duccio, Simone Martini, Lorenzo Monaco, Gentile da Fabriano, and a multitude of other 'lateGothic' artists, whose styles were tethered to medieval art. Giotto and Masaccio broke from Gothic conventions and paved the way for Renaissance painting.

Thus, in keeping with its economic rationality, derived from banking and other commercial activities, the progressive upper-middle class held a worldview that 'was secular and life-affirming, expressed action and energy, was sober, logical and calculated' (Antal, 1948: 289). Naturalism and classicism were the visual expressions of this rational outlook because they spurned the otherworldliness of Gothic and Byzantine conventions. Antal critically contrasts this progressive sensibility with the late-Gothic styles of the same period, which he argues were emblematic of symbolic and aristocratic modes of Medieval thought. This perspective was extended to religious sentiment and patronage. Of the great mendicant 
orders, the Franciscan and Dominican, the upper-middleclass preferred to patronise the latter. Franciscan poverty, even if largely notional, did not appeal to its mercantile interests. Also, the philosophical system of Saint Thomas Aquinas, a Dominican, was more conducive to the intellectual outlook of the cultural elite. For this reason, Antal placed Fra Angelico, a Dominican friar, on the side of rationalism and classicism.

While conventional art history identified styles based on their formal characteristics, social history attempted to explain styles based on their implied ideological outlooks. However, Antal's attempts to apply his concepts to the history of the $14^{\text {th }}$ and early- $15^{\text {th }}$ centuries, led to a complicated picture of Florentine art and society. After Giotto's death in 1337, advanced Florentine art entered a period of decline for most of the $14^{\text {th }}$ century. This was occasioned by the collapse the banking houses of Bardi and Peruzzi and the calamitous effects of the Black Death of 1348 . In the third quarter of the $14^{\text {th }}$ century, when the lower-middleclass gained a share of political power, the progressive upper-middleclass was forced to make artistic concessions to petty bourgeois tastes. It did so by giving its own art a more 'popular' sentiment, as indicated by Andrea da Firenze and Niccolo di Tommaso. Although the upper-middleclass regained control of Florentine society in the 1380s, a period that coincided with the art of Spinello Aretino, a follower of Giotto, its fortunes were short-lived. Henceforth, after a period of economic decline, political authority in Florence was concentrated in the hands of a few powerful families.

Antal's stylistic analysis is often complex and contradictory, especially when related to the political and economic vicissitudes of Florentine society. During a period of social instability, when sections of the upper-middleclass assumed aristocratic lifestyles and values, it was no longer possible to determine any definite style or direction in art. Because the nobility and the lower-middleclass were both culturally backward, art at this time reflected the popular tastes of the petty bourgeoisie and the reactionary (Gothic) tastes of the aristocracy. The art of 
the early Quattrocento is therefore described as a blend of 'popular,' 'aristocratic' and 'rational' styles, thus reflecting 'the many-sidedness of the mentality of the Florentine upper middleclass' and its changing social circumstances (Antal, 1948: 315). This mishmash of styles was represented by Lorenzo Monaco (described as 'popular-aristocratic'), Gentile da Fabriano ('aristocratic') and Masaccio ('intellectual' and 'classical').

\section{On the social position of the artist}

Antal's class-based account of the social position of the artist and the role of the patron, in determining the emergence of early Renaissance styles, was especially controversial. Because artists were generally of inferior social position, and were largely dependent on their patrons' largesse, 'their own economic and social conditions affected the development of art less than did those of their patrons, whose outlook on life was the ultimate factor in determining the emergence and interrelations of the various styles' (Antal, 1948: 274). In the $14^{\text {th }}$ century, when there was no clear dividing line between the arts and crafts, 'artists-including of course painters — had to satisfy every possible requirement of their clients' (ibid.: 280). The dependent relationship between artist and patron enabled Antal to view style not as an expression of artistic personality or singular genius, but rather as an expression of class attitudes and ideology. In this way, the artist was a medium through which the patron expressed their classbased worldview. 'Differences of opinion between artist and patron as to the style of a painting,' says Antal, 'were probably rare; the patron would almost invariably have selected artists whom he could expect to work to his satisfaction' (ibid.: 283). It was anachronistic, Antal argued, to think of the artist in $20^{\text {th }}$ century terms, as an autonomous creative agent.

The freedom of the artist which, of course, did not exist in the modern sense, was confined within the framework of his rigidly prescribed commission. In 
general it was the rule that the painter was regarded as a craftsman and therefore should have no more freedom with his work than the latter would. (ibid.)

Thus, in the $14^{\text {th }}$ century, the profession of the artist had not yet attained any special aura and painting was still regarded as one of the manual crafts. Antal reminds the reader that in the pre-bourgeois era 'art's only raison d'être was to give a reflection, even though a pale one, of a religious idea,' and that the theological worldview of the Middle Ages 'placed little value on art considered as observation of nature or as representation of physical beauty' (Antal, 1948: 274). In the eyes of the Church, art as such had no theoretical foundation.

In the encyclopaedias and in the Summae, painting and sculpture found no place among the seven artes liberales which were regarded by the Church as the higher spiritual disciplines, founded on knowledge and possessed of a theoretical basis. As a rule they did not count even among the seven artes mechanicae which were based on practice and skill. From the Church's standpoint they were simply regarded as artisanship, in accordance with their menial, inferior position. (ibid.: 275)

Progress towards the autonomy of art began slowly in Italy in the $14^{\text {th }}$ century. It was here that the nascent middleclass achieved its greatest political and economic influence. Intellectual attitudes about art were more advanced in the bourgeois republic of Florence than in other Italian cities or the northern countries. Although the position of the Church was accepted on matters of art, concessions were made to the Florentine middleclass when cultural questions did not threaten the official ecclesiastical viewpoint. Evidence of the early autonomy 
of art can be found in a more private attitude towards religious art, as well as the relative secularisation of art, and above all in the increasing influence of the laity in artistic commissions (Antal, 1948: 276). As Antal saw it, artistic freedom was most pronounced during the dominant phases of the progressive upper-bourgeoisie. It was during these periods of material and intellectual advancement 'when certain of the artists were able to regard themselves as members of the upper middle class' (ibid.: 283). Creative freedom was therefore commensurate with the social position of the artist. In other words, artistic authority increased in periods of social progress and declined in periods of political reaction. The best artists could ascend the social hierarchy when the progressive upper-middleclass flourished, rising from the ranks of manual artisans to bourgeois citizens. Antal reminds the reader that Giotto grew affluent and lived the life of a wealthy citizen and not a simple craftsman. Yet, despite the potential for social mobility, an artist's status was dependent on that of their patrons. Since,

The more eminent the social position of the patron and the more the kind of work commissioned necessitated personal contact between patron and artist, the more highly would the personal achievement of the artist be valued, and his social standing and professional consciousness increase. (ibid.: 281)

The subordination of the artist to the patron, in matters of creative licence, was the most contentious feature of Antal's project. For many readers and critics, this prescriptive arrangement not only reduced the artist to an agent of the patron's class interests; it had also deprived art of its cultural autonomy. For liberal critics, this position challenged the individual sovereignty of the artist and the humanist conception of Renaissance genius (Martindale, 1972). For New Left critics, eager to distance themselves from the strictures of 'scientific' Marxism, it was a figment to attribute 'a complete depiction of the consciousness of a class' to 
a 'representative artist' (Clark, 1974: 562). However, Antal's view of the social position of the artist was not entirely based on Marxian class struggle or sociological theories of the division of labour. The historiography of the artist had been a preoccupation of the Vienna School of Art History before Antal's 'methodological turn' in favour of historical materialism.

The theory of the artist was the focus of study of Julius von Schlosser and his students, Ernst Kris and Otto Kurz (Kris and Kurz, 1979). 'In the case of the theory of the artist,' says Catherine Soussloff, 'this is particularly relevant because both textual and historical investigations into the concept of the artist occurred in Vienna from about 1905 to 1934' (Soussloff, 1997: 99). Von Schlosser was the leading partitioner of the 'philological' approach to art history in Vienna. In his book, The Literature of Art: A Handbook on the Source of Recent Art History (Die Kunstliteratur: ein Handbuch zur Quellenkunde der neueren Kunstgeschichte), published in 1924, von Schlosser systematically organised the primary and secondary literature of Italian art into chronological order. Von Schlosser held the biography of the artist in a privileged and isolated status, thereby 'locating the basis of the origin of art history in an essential narrative form, in a text he considered to be biographical, in an author also an artist, and in a style of writing considered to be truthful' (ibid.: 103). Antal's historical inquiry into the social position of the artist was not intended as a critique of von Schlosser's philological approach; indeed, Antal drew heavily on this scholarship for his own research. Rather, in providing an historical background to this literature, he sought to establish a more solid historical basis for von Schlosser's textual representation of the artist.

Thus, Antal presented an historical materialist interpretation of the mythology of the artist as presented by Kris and Kurz in their book, Legend, Myth, and Magic in the Image of the Artist. This work, first published in Vienna in 1934, investigates the legend of the artist in Renaissance texts, revealing certain stereotypical qualities indicative of the personality of the artist. In this literary genre, the heroic artist stands above society. Common tropes from artist 
biographies include accounts of artistic precocity, often involving the presence of portents or harbingers of artistic genius; exceptional virtuosity in artistic media without laboured effort; intense or unusual spirituality or wisdom; and magical influences ascribed to artistic production (Soussloff, 1996: 97; Kris and Kurz, 1979). Like von Schlosser, Antal upheld the artist's biography as a privileged genre of art literature. However, instead of viewing these texts as objective or transparent accounts of art history, he saw them as inventions of liberal ideology, in which creative autonomy disguised the artist's material struggle for independence. The symbolic representation of the subject of the artist, in the form of literary biography, was therefore evidence of the artist's new social status and emancipation from the medieval craft system.

Lorenzo Ghiberti's Commentarii exemplifies this genre and attests to the new social status accorded to the artist in the early- $15^{\text {th }}$ century. It was, as Antal notes, the first book to translate Pliny's stories about ancient artists into Italian and the first artistic autobiography, in which Ghiberti includes descriptions of his own works. Its influence was far-reaching, providing a model for Vasari's Lives of the Most Excellent Painters, Sculptors, and Architects, published in the mid- $16^{\text {th }}$ century. Ghiberti was a member of the elite circle of Cosimo de' Medici and the humanist scholar, Niccolò de' Niccoli. With the Commentarii, Ghiberti sought to expound the theoretical basis of art, the importance of which was emphasised in accordance with the new rationalist outlook of Quattrocento Florence. As Antal saw it, 'The ultimate aim of his [Ghiberti's] book was to contribute to the improvement of the social position and to the education of the artist' (Antal, 1948: 376). Ghiberti's Commentarii are contrasted with an earlier, technical treatise on painting written by Cennino Cennini in the 1390s. Whereas Cennini looked upon painting as a form of manual dexterity, Ghiberti desired to establish its theoretical foundations: 'He particularly wanted to make his scientific knowledge accessible to other artists: in the fields of optics, perspective, anatomy, and the theory of proportion' 
(ibid.). Thus, artists who were able to place their art at the service of theoretical or scientific knowledge were more likely to achieve social independence:

It was by establishing a theoretical and scientific foundation for itself that art could obtain greater social recognition, could free itself from the crafts, and so those who practised it could rise from the condition of artisans close to the upper middle class. (ibid.)

With a greater importance attached to optics, geometry and perspective, painters and sculptors now shared their technical and theoretical knowledge with architects and philosophers. The technical and mathematical studies of Brunelleschi would therefore greatly interest Ghiberti, Masaccio, Donatello and Uccello. Antal viewed these developments as signs of a new professional artistic self-assurance. And yet, the esteem in which these artists were held was always commensurate to the prestige of their commissions and patrons. Artists enjoyed their highest social status at times when art and the ideas of the progressive uppermiddleclass were mutually complementary. Hence, when concepts from the scientific and philosophical literature of antiquity came to be applied to art, 'art was brought nearer to science and so given a higher standing, a social prop' (Antal, 1948: 375). The social composition of artists would also change at times when art enjoyed a greater intellectual reputation. Many artists no longer came from the old artisan class. Instead, they sprang from middle-class surroundings, and became artists not from necessity but rather from 'talent and conviction'.

Masaccio, for instance, was the son of a notary, and Brunelleschi came from a rich and noble family. Though it must not be overlooked that Brunelleschi, Ghiberti and Donatello were originally goldsmiths, these bourgeois artists 
already felt themselves to be in some ways men of science; they were on friendly terms with scientists or scientifically educated laymen from the upper middle class. (ibid.: 377 )

\section{Legacy and critique}

Anthony Blunt was among the first English art historians to adopt the 'scientific' methods of Central European art history. In his book, Artistic Theory in Italy, 1450-1600, published in 1940, Blunt acknowledged his indebtedness to the Warburg Institute, where he had 'the inestimable advantage of seeing a really scientific method consistently applied' (Blunt, 1940: vi). Blunt also acknowledged the influence of Antal, who, by his own account, had had the greatest impact on his new approach to art history: 'To Dr. F. Antal I am indebted for instruction in a method which has, I fear, been applied in an only too slipshod manner in this book' (ibid.). Chapter four of Artistic Theory in Italy, 'The Social Position of the Artist,' was inspired by Antal's current research in this area. Indeed, Blunt's book offered a taste of the social and intellectual history of art later expounded by Antal in Florentine Painting and its Social Background.

Antal did not want art history to be absorbed into the category of social or general history. Rather, he saw Marxism as a perspective through which art history could be reinterpreted and reanalysed. Historical materialism could add methodological rigour to existing art-historical knowledge and build upon the achievements of Dvořák and the meticulous scholarship of the Vienna School. Most importantly, for Antal, Marxist analysis could explain the development of styles in historically objective terms. Whereas Dvořák's history of ideas was unscientific and based on an abstract notion of autonomous spirit, historical materialism was a method that provided a 'scientific' understanding of the social conditions of cultural production. The new scientific perspective proposed by Antal could 
therefore build upon, and finally exceed, Dvořák's Geistesgeschichte and von Schlosser's philology. However, replacing Dvořák’s spiritual worldview with one based on dialectical materialism would expose Antal (and Dvořák) to criticism from both liberal and Left-leaning scholars.

When explaining why Dvořák’s legacy was neglected by academic art historians in the post-war decades, Matthew Rampley has blamed a tendency to misconstrue his work as popular, grandiose, or nationalistic (Rampley, 2003: 214). But Dvořák’s writings may also have been too closely associated with Antal and his reductive historicism. Paul Stirton is correct in his assessment of Dvořák, that he 'introduced the possibility of a social history of art in which artefacts could be understood and interpreted in terms that reflected the society in which they were created' (Stirton, 2006: 48). Gombrich, a vocal and persistent critic of both historical materialism and idealism, shared this view. He would often conflate both tendencies: 'From my student days in Vienna I had become increasingly sceptical of the solutions offered by Neo-Hegelian Geistesgeschichte and Neo-Marxist Sociologism' (Gombrich, 1979: 60). As noted earlier, Gombrich's critique of the social history of art was an extension of Karl Popper's arguments against historicism and determinism, tendencies he believed to be implicit in sociology (Berryman, 2017).

Antal's account of the social position of the artist vis-à-vis the patron, in determining the development of styles, was his most challenging contribution to art history. Later art historians engaging with the social history of art were forced to wrestle with this legacy. This was most problematic for New Left writers working within the broad Marxist tradition. In 1973, when outlining his approach to the social history of art, T.J. Clark disavowed the earlier work of the so-called scientific Marxists. For Clark, their crude application of historical materialism was too mechanical. 'When one writes the social history of art,' wrote Clark in his manifesto 'On the Social History of Art,' 'it is easier to define what methods to avoid than to 
propose a set of methods for systematic use' (Clark, 1973: 10). Clark began by naming some of his taboos: 'I am not interested in the notion of works of art "reflecting" ideologies, social relations, or history.' In a veiled reference to Antal, 'I do not want to talk about history as "background" to the work of art' (ibid.).

However, before concluding, it must be noted that not all practitioners of the social history of art worked within a Marxist tradition or theoretical framework. Francis Haskell described his approach as 'severely empirical' and not ideological. In his social history of Baroque art, Patrons and Painters, Haskell deliberately avoided any attempt to 'explain' art in terms of patronage. He wrote: 'I have been forced to think again and again about the relations between art and society, but nothing in my researches has convinced me of the existence of underlying laws which will be valid in all circumstances' (Haskell, 1980[1963]: viii). On some occasions, Haskell found the connections between economic and political conditions and certain styles to be particularly close; at other times, however, he conceded that he was unable to 'detect anything more than the internal logic of artistic development, personal whim or the workings of chance' (ibid.).

Like Haskell, Michael Baxandall wrote social history free of Marxist interpretation. Baxandall covers similar territory to Antal, focusing on the art of the Quattrocento. In his book, Painting and Experience in Fifteenth Century Italy: A Primer in the Social History of Pictorial Style, Baxandall points out that 'social history and art history are continuous, each offering necessary insights into the other' (Baxandall, 1988[1972]: page unnumbered). In other words, art history and social history are methodologically complementary. Like Haskell, Baxandall's method was deeply empirical. He used archival documents and primary sources to explore the $15^{\text {th }}$ century picture trade and to find an economic basis for 'the cult of pictorial skill' (Baxandall's phrase). Importantly, Baxandall devised the concept of 'period eye' to explain the vernacular visual skills of $15^{\text {th }}$ century Italians; that is, the visual competencies used in daily 
life by people to understand pictures in their social, religious and commercial contexts. Based on concepts used by Cristoforo Landino, a contemporary Florentine art critic of Quattrocento pictures, Baxandall assembled a visual 'equipment' for looking at $15^{\text {th }}$ century pictures in $15^{\text {th }}$ century terms. This historical perspective offered 'an insight into what it was like, intellectually and sensibly, to be a Quattrocento person' (ibid.: 152).

Whereas Baxandall began his book by noting how styles of painting responded to contemporary social circumstances, he concluded by reversing the equation, by suggesting how modern viewers could use 'the period eye' to sharpen their perceptions of historical societies. This is important, says Baxandall, because a society develops its own distinctive visual skills and habits, and these become part of the medium of the painter. The modern viewer must therefore learn to look at pictures like a member of that bygone society. This perspective was in contrast to certain art historians of a Marxist persuasion, who viewed pictorial styles through the prism of modern class consciousness and who saw art as a means of 'illustrating' social history. Without naming Antal or Hauser, Baxandall was especially critical of the schematic and formulaic interpretations of historical materialism, especially a tendency to rigidly identify styles of art with modes of production (e.g. capitalism). Baxandall denounced these approaches as 'destructive uses of pictures which must be avoided' (Baxandall, 1988[1972]: 152).

Antal's most controversial topics, concerning the social status of the artist and the material preconditions of artistic production, had more in common with the sociology of art, which investigated the social construction of the artist. Pierre Bourdieu and Howard Becker, pioneering sociologists in this area, examined the contexts and networks in which works of art were produced and consumed. Western 'art worlds', says Becker, follow an 'intensely individualistic theory of art,' perpetuating the idea that 'specially gifted people create works of exceptional beauty and depth' (Becker, 1982: 352-3). Bourdieu's systematic sociology includes the formulation the 'field of cultural production,' a social system in which cultural 
goods are collectively produced and appropriated, and where agents compete for 'cultural capital.' The social and political struggles of the field are concealed by disinterested ideals. Bourdieu describes the artist-centric discourse as the 'charismatic ideology.' This ideology privileges individual creativity while marginalising the actions of other agents engaged in the field (among them patrons, critics, collectors, curators) who together, 'participate in the production of the value of the artist and of art' (Bourdieu, 1993: 261). Thus, 'it is this ideology which directs attention to the apparent producer, the painter, writer or composer, in short, the 'author', suppressing the question of what authorises the author, what creates the authority with which authors authorise' (ibid.: 76, original emphasis).

When Florentine Painting was published, the 'charismatic ideology' of the artist informed the basic assumptions of disciplinary art history. Style was seen as a singular attribute of the artist and an expression of creative autonomy. This inalienable belief also informed much of the criticism of Antal's book. Antal's project was ambitious; it aimed to produce a comprehensive history of Renaissance art based on a synthesis of cultural, economic and political factors. In considering artistic styles as specific combinations of these elements, works of art were thereby no longer viewed in purely formal or individual terms, as isolated aesthetic objects. Instead, a work of art's style was an expression the social and ideological outlook of its public. The artist was the agent through which this social outlook was expressed.

\section{Conclusion}

Antal was over 60 years old when Florentine Painting and its Social Background was finally published. He did not live long enough to defend its legacy or answer his critics. Antal's legacy can therefore be compared with that of Arnold Hauser, his contemporary; whereas Antal died in 1954, Hauser lived until 1978. Hauser, who was a similar age in 1951 when The Social History of Art was published, was able to defend his work. In response to his critics, Hauser 
published a detailed methodology and rationale of his research (Hauser, 1959). And with the publication of Mannerism in 1964, Hauser was able to demonstrate a more refined and focused application of social history, while downplaying the Marxist overtones of his earlier work (Hauser, 1964). Antal's widow, Evelyn Antal, oversaw the editing and posthumous publication of his few completed manuscripts. Of the younger generation of New Left critics, John Berger was among the few who defended Antal's 'orthodox' Marxism (Berger, 2016: 33-6). Francis Haskell, a leading art historian of the post-war generation, was more qualified in his assessment; on the one hand he acknowledged Antal's 'many contributions' and 'flashes of insight', while at the same time rejecting the 'dogmatic and over-simplified' aspects derived from historical materialism (Haskell, 1968: 161).

Antal's book became a caricature of the mechanistic and deterministic tendencies of historical materialism. It is remembered, if at all, as an approach to be avoided. However, the book should also be remembered for its achievements and its ambitions, which have been ignored or forgotten by many of its critics. The most important of which was Antal's efforts to broaden the scope of art-historical research, and in keeping with its place in the human sciences, to provide art history with a solid methodological grounding. Jonathan Harris has quoted from a letter by Alan Wallach, supporting the republication in 1999 of Arnold Hauser's Social History of Art: 'If today the boundaries of the discipline seem more permeable, more open to scholarship in other fields than when Hauser wrote, it is in no small measure due to his pioneering effort' (Harris, 2001: 89). The same must be said about Antal and his 'pioneering' book, Florentine Painting and its Social Background, which preceded Hauser's book by three years.

Many readers and critics in the 1950s were confounded by Antal's explanation of early Quattrocento Florentine painting, with its 'many-sided' and conflicting mixture of classical, rational and late-Gothic styles. Indeed, an account based on 'the co-existence of various styles 
in the same period and in the same place' was atypical, especially at a time when art history was defined by linear period styles and modernism by successive style-based movements. However, after several decades of postmodernism, this description should seem less perplexing. Charles Jencks, for example, describes the plurality of styles and attributes of postmodern culture as 'double-coded,' in which 'differing tastes and opposite forms of discourse' coincide (Jencks, 1992: 13). Antal's understanding of Florentine painting was 'double-coded' in a general sense. His account of Florentine art and society might therefore appear more familiar to a new generation of historians and critics, and to a contemporary art world where disparate and contradictory styles readily coexist.

\section{References}

Antal, F. (1924/1925) 'Gedanken zur Entwicklung der Trecento- und Quattrocento-malerei in Siena und Florenz' [Thoughts on the Development of Trecento and Quattrocento Painting in Siena and Florence], Jahrbuch Für Kunstwissenschaft: 207-39.

Antal. F (1925) 'Studien zur Gotik im Quattrocento: Einige Italienische Bilder des KaiserFriedrich-Museums' [Studies of Gothic in the Quattrocento: Some Italian pictures of the Kaiser Friedrich Museum], Jahrbuch Der Preuszischen Kunstsammlungen 46: 332.

Antal, F. (1948) Florentine Painting and its Social Background: The Bourgeois Republic Before Cosimo de' Medici's Advent to Power: XIV and Early XV Centuries. London: Kegan Paul.

Antal, F. (1956) Fuseli Studies. London: Routledge \& Kegan Paul.

Antal, F. (1962) Hogarth and His Place in European Art. London: Routledge \& Kegan Paul.

Antal, F. (1966) Classicism and Romanticism, With other Studies in Art History. London: Routledge \& Kegan Paul. 
Antal, F. (1976[1932]) ‘Über Museen in der Sowjetunion’ [On Museums in the Soviet Union] Kritische Berichte zur Kunstgeschichtlichen Literatur 4: 5-11.

Antal, F. (1979[1946]) 'Letter to Georg Lukács', in Wessely, A. (1979) ‘Antal and Lukacs Marxist Approach to the History of Art', New Hungarian Quarterly 20(73): 114-25.

Azatyan, V. (2010) 'Ernst Gombrich's Politics of Art History: Exile, Cold War and "The Story of Art", Oxford Art Journal 33(2): 129-41.

Baxandall, M. (1988[1972]) Painting and Experience in Fifteenth Century Italy: A Primer in the Social History of Pictorial Style. Oxford: Oxford University Press.

Becker, H. S. (1982) Art Worlds. Berkeley: University of California Press.

Berger, J. (2016) Landscapes: John Berger on Art. London: Verso.

Berryman, J. (2017) 'Gombrich's Critique of Hauser's Social History of Art', History of European Ideas 43(5): 494-506.

Blunt, A. (1940) Artistic Theory in Italy, 1450-1600. Oxford: Clarendon Press.

Blunt, A. (2004[1971]) ‘Antal, Frederick (1887-1954), Art Historian', Oxford Dictionary of National Biography. Retrieved 9 Sep. 2019, from https://www.oxforddnb.com/

Bourdieu, P. (1993) The Field of Cultural Production: Essays on Art and Literature. Cambridge: Polity.

Childe, V. G. (1936) Man Makes Himself. London: Watts.

Clark, T. J. (1973) Image of the People: Gustave Courbet and the 1848 Revolution. London: Thames and Hudson.

Clark, T. J. (1974) 'Art History: The Conditions of Artistic Creation', The Times Literary Supplement, 24 May: 561-2.

Congdon, L. (2001) Seeing Red: Hungarian Intellectuals in Exile and the Challenge of Communism. DeKalb, Ill: Northern Illinois University Press. 
Dvořák, M. (1984) The History of Art as the History of Ideas. London: Routledge \& Kegan Paul.

Frank, T. (2009) Double Exile: Migrations of Jewish-Hungarian Professionals through Germany to the United States, 1919-1945. Bern: Peter Lang.

Gombrich, E. H. (1979) Ideals and Idols: Essays on Values in History and in Art. Oxford: Phaidon.

Gronau, H. (1948) 'Florentine Painting and Its Social Background', The Burlington Magazine 90(547): 297-8.

Habermas, J. (1989) The Structural Transformation of the Public Sphere: An Inquiry into a Category of Bourgeois Society. Cambridge: Polity.

Harris, J. (2001) The New Art History: A Critical Introduction. London: Routledge.

Haskell, F. (1968) 'Classicism and Romanticism, with Other Studies in Art History by Frederick Antal', The Burlington Magazine 110(780): 161-2.

Haskell, F. (1980[1963]) Patrons and Painters: A Study in the Relations Between Italian Art and Society in the Age of the Baroque. New Haven: Yale University Press.

Hauser, A. (1959). The Philosophy of Art History. New York: Knopf.

Hauser, A. (1964). Mannerism: The Crisis of the Renaissance and the Origin of Modern Art. London: Routledge \& Kegan Paul.

Jencks, C. (1992) 'The Post-Modern Agenda', in C. Jenks (ed.) The Post-Modern Reader. London: Academy Editions pp. 10-39.

Kris, E. and Kurz, O. (1979) Legend, Myth, and Magic in the Image of the Artist: A Historical Experiment. New Haven: Yale University Press.

Krohn D. L. (1999) 'Antal and his Critics: A Forgotten Chapter in the Historiography of the Italian Renaissance in the Twentieth Century', in W. Reinink and J. Stumpel (eds) Memory \& Oblivion. Dordrecht: Springer, pp. 95-9. 
Martindale, A. (1972) The Rise of the Artist in the Middle Ages and Early Renaissance. London: Thames and Hudson.

Meiss, M. (1949) 'Florentine Painting and Its Social Background by Frederick Antal', The Art Bulletin 31(2): 143-50.

Mommsen, T. (1950) 'Frederick Antal's Florentine Painting and its Social Background', Journal of the History of Ideas 11(3): 369-79.

Orwicz, M. R. (1985) 'Critical Discourse in the Formation of a Social History of Art: AngloAmerican Response to Arnold Hauser', Oxford Art Journal 6(2): 52-62.

Pope-Hennessy, J. (1991) Learning to Look. New York: Doubleday.

Rampley, M. (2003) 'Max Dvořák: Art History and the Crisis of Modernity’, Art History 26(2): 214-37.

Rampley, M. (2013) The Vienna School of Art History: Empire and the Politics of Scholarship, 1847-1918. University Park, Penn.: Pennsylvania State University Press.

Snowman, D. (2002) The Hitler Émigrés: The Cultural Impact on Britain of Refugees from Nazism. London: Chatto \& Windus.

Soussloff, C. M. (1997) The Absolute Artist: The Historiography of a Concept. Minneapolis, MN: University of Minnesota Press.

Stirton, P. (2006) 'Frederick Antal', in A. Hemingway (ed.) Marxism and the History of Art: From William Morris to the New Left. London: Pluto Press, pp. 45-66.

Stirton, P. (2013) 'The Vienna School in Hungary: Antal, Wilde and Fülep', Journal of Art Historiography 8: 8-PS/1.

https://arthistoriography.files.wordpress.com/2013/06/stirton.pdf

Tanner, J. (2003) 'Introduction: Sociology and Art History', in J. Tanner (ed.) The Sociology of Art: A Reader. London: Routledge, pp. 1-26. 
Wessely, A. (1979) 'Antal and Lukacs - Marxist Approach to the History of Art', New Hungarian Quarterly 20(73): 114-25.

Wolff, J. (1983) Aesthetics and the Sociology of Art. London: Allen \& Unwin.

\section{Author biography}

Jim Berryman works as a librarian at the University of Melbourne. He has a $\mathrm{PhD}$ in art history from the Australian National University in Canberra. His interests include art historiography, art documentation, intellectual history, and Australian cultural history. His research has been published in Australian and international journals. 


\section{University Library}

\section{- M M I N E R VA A gateway to Melbourne's research publications}

Minerva Access is the Institutional Repository of The University of Melbourne

Author/s:

Berryman, J

Title:

Frederick Antal and the Marxist challenge to art history

Date:

2021

Citation:

Berryman, J. (2021). Frederick Antal and the Marxist challenge to art history. History of the Human Sciences, 35 (2), pp.55-76. https://doi.org/10.1177/09526951211003779.

Persistent Link:

http://hdl.handle.net/11343/274715 